Call for Papers

\title{
Management and Organization Review
}

\section{Research Frontiers Conference and Paper Development Workshop 'China's Outward Foreign Direct Investment to Africa'}

\author{
Local Host: Gordon Institute of Business Science, \\ University of Pretoria \\ Conference Organizers and Program Committee: \\ Professor Helena Barnard, University of Pretoria \\ Deputy Editor, Management and Organization Review \\ Arie Y. Lewin, Duke University \\ Editor-in-Chief, Management and Organization Review \\ Elizabeth L. Rose, Leeds University
}

\section{Guest Editors of MOR Special Issue}

Professor Helena Barnard, University of Pretoria

Professor Abdoulkadre Ado, University of Ottawa

Professor Peter Ping Li, Nottingham University Ningbo China

Professor Michael A. Witt, INSEAD, Singapore

\section{Co-Sponsors:}

Centre for International Business at the University of Leeds (CIBUL), University of Leeds Technology and Management Centre for Development (TMCD) Oxford University University of San Francisco, China Business Studies Initiative Duke University, Asia Pacific Studies Institute

Dates: July 15-18, 2021

Chinese investment is transforming the African landscape. Pot-holed roads are being replaced by double-lane highways. In urban areas, Chinese-built office complexes, hotels, and shopping malls are an increasingly common sight and in even remote rural areas, Chinese traders are selling Chinese-made essentials to locals. 
Africa is the last frontier to offer abundant investment opportunities to an economy with national capabilities in executing large-scale infrastructure projects. FDI projects in Africa are an integral aspect of the Bridge and Belt globalization national initiative. It contributes to maintaining employment of Chinese workers in strategically important infrastructure industries, an important national consideration as China balances the transition to a service economy, increased domestic consumption, spiraling domestic debt and an ageing population. China, being the largest foreign investor in Africa, has attracted mixed views from inside and outside Africa for its investment on this continent and has been criticized by Western Countries for neo- colonialization behavior.

China OFDI into Africa helps create new opportunities given current environment in China and is taking place in an era during which global economic activity is transforming. De- globalization dynamics, the 4th industrial revolution arising from digitalization, artificial intelligence, platformization, 3D printing etc. that are predicted to transform global trade, give rise to more regional trade compacts, and redefine global value chains. This highlights the huge opportunities for the development of technologically less advanced economies - markets.

European and American multinationals have been slow to take advantage of investment opportunities in Africa. Large-scale infrastructure development requires huge capital investment financing. The Western developed economies are either not willing or not able to match China OFDI policies for such projects. Even when financing can be arranged, there has been a lack of interest and the quite recent colonial history complicates the relationship between Africa and especially European countries.

This does not mean that reported concerns of neocolonialism and power dependencies are absent from the China/Africa relationship. Facing the pressures of economic development and projected population growth, many African countries are attracted to the top-down state capitalism approach exemplified by the history of China since opening up in 1978 and by President Xi's aspirations for China to challenge the dominance of the US. Chinese FDI into Africa also reinforces an affinity between countries that question the efficacy of liberal democratic institutional configurations in how they govern. In an era of increasing populism, rising forces of de-globalization and the ratcheting economic competition between the US and China, such an affinity has far-reaching implications.

This Management and Organization Revieze research frontiers conference and paper development workshop will culminate in a special issue of MOR focused on exploring the history, experience, and implications of Chinese FDI into Africa. Given the wide range of topics, disciplinary perspectives, empirical approaches, and the nature of the questions raised by Chinese FDI into Africa, the program committee and the guest editors hope to attract scholars from a range of disciplines such as international business, political science, corporate strategy, organization theory, cross cultural research, social movements and others. 
The MOR research Frontiers Conference on China OFDI to Africa is therefore seeking papers that provide insight into why and how Chinese FDI into Africa is playing out. Especially welcome are scholars whose research can contribute to elucidate how Africans understand Chinese FDI on their continent, as well as also explorations of the Chinese perspective. The conference seeks to feature rigorous scholarly contributions including micro perspectives of how individuals experience Africa/China interactions, large-scale macro perspective on the phenomenon, conceptual contributions and qualitative case studies. But beyond that, the organizers and guest editors are not imposing specific themes or research questions.

The deadline for submitting papers is August 28, 2020. Authors whose papers receive a Revise and Resubmit Editorial decision will be notified that their paper has been accepted for the Paper Development Workshop by January 15, 2021. Revised papers will be due by May 21, 2021.

The Research Frontiers Conference will also feature 4-6 plenary sessions. To broaden the range and mix of the plenary session the program committee and the guest editors are inviting panel proposals. A panel session consists of 3-4 panelists and the Chairperson. Each panel will run for 120 minutes including 30 minutes for engaging the audience. Please submit panel session proposals by October 30, 2020. Panel proposal should consist of an extended abstract and 2-4 pages describing the expected contribution of each panelist, their bio sketch and letters confirming their participation in the conference if the panel proposal is accepted for discussion in the Research Frontiers Conference.

\section{Submission information:}

Please submit full papers by 28 August 2020 via the MOR (Cambridge) website: https://mc.manuscriptcentral.com/mor

It is important that all papers for the special issue conform to MOR's submission requirements.

Please submit panel proposals by 30 October 2020 via email with subject line 'China OFDI to Africa Panel Proposal' to MORManagingeditor@cambridge.org 